\title{
Teacher's Perception Towards Student Work Sheets with Ethnoscience Approach
}

\author{
Yayuk Andayani* \\ Science Education of Study Program Pastgraduate \\ University of Mataram \\ Mataram, Indonesia \\ *yayukmtr@unram.ac.id
}

\begin{abstract}
This study aims to assess how high school chemistry teachers value the student worksheets with the ethnoscience approach. Teachers' perceptions were collected using questionnaire with a Likert scale. Teachers rated the worksheet on an ordinal scale and the values were descriptively analyzed. The assessment of the worksheet covers of technical aspect, content, and constructive aspect. The results of the study showed that the chemistry teacher's perception of the student worksheets with the Ethnoscience approach was valued as a good criterion and may provide alternative learning materials for teaching chemistry joyfully.
\end{abstract}

Keywords-teacher perception, chemistry, ethnoscience approach, student worksheet

\section{INTRODUCTION}

Indonesia has around 633 ethnic groups [1] scattered throughout the archipelago, however this cultural diversity has not been developed as a source of learning in schools. Ethnoscience is indigenous science possessed by a certain cultural and linguistic community [2-3], which is related to the cognitive map of a society [4].

Ethnoscience reflects the thinking of the indigenous people themselves about how to classify their world physically. The constructivism studies open human thought to see science not only as a systematic knowledge, but also as a way of thinking. So, ethnoscience is seen as intuitive knowledge that is built up since students are children through other people (parents or peers), so that these values should be integrated in learning. Unfortunately, this knowledge has received less attention from education practitioners, including science teachers in Indonesia.

Learning using an ethnoscience approach is very important for students [5] because the success of the science learning process in school is strongly influenced by the cultural background of the students or the community in which the school is located [6,7]. Therefore, the teachers as one of the components in the education system plays an important role in teaching cultural values to students. In fact, teachers have difficulty connecting the concepts, processes and contexts of science with scientific knowledge so that the integration of local culture that develops in society into science learning is still limited [8].

The difficulty of connecting existing scientific concepts in local culture of the local community (ethnoscience) to chemistry learning can occur because teachers do not have enough knowledge, experience and awareness to teach about cultural diversity [9]. In addition, teacher's perception and attitude ethnoscience will influence the way teachers think and concepts taught to students.

Based on the result of observations about the ethnoscience experiences of Chemistry teachers and students involving 20 senior high school in Lombok, it is known that $63 \%$ of teachers stated that they have never made learning resources that the link ethnoscience. In line with these results, $61 \%$ of students stated that the teacher had never linked ethnoscience knowledge with learning material or learning resources. This shows that the presentation of learning resources for chemistry seems to be separate from the world where students live in their daily activity.

One of the learning resources that can connect cultural or ethnocentric aspects with classroom learning is through Student Worksheet. The manufacture of Sasambo and Jaje Timbung batik is a cultural treasure that has long developed in lombok area but has not been used as a source of chemical learning in schools. In this research has been compiled students' worksheet with an ethnoscience approach that integrates the manufacture of Sasambo batik and Jaje Timbung into chemical learning materials. So that LKPD can be used by teachers in chemical learning, there needs to be a study of the teacher's perception of student worksheet with an ethnoscience approach and examine the problems that teachers may face related to knowledge, application and teacher's perception of ethnoscience.

This study aims to describe the chemistry teacher's perception of the student worksheet using the ethnoscience approach in high school chemistry materials. The teacher's perception in question is the chemistry teacher's response after reading the student worksheet containing ethnoscience, because the perception arising from the teacher comes from their respective views on student worksheet containing these 
ethnoscience. The results of this study are expected to help chemistry teachers and students who need learning resources with an ethnoscience approach.

\section{METHODS}

This research is a descriptive study with a quantitative approach, which involved 34 chemistry teachers as respondents from 16 state senior high schools in two districts in Lombok NTB. Data on teacher perception was measured using a closed questionnaire consisting of 27 statement items from three aspects, namely technical, content and construct. The questionnaire's choice of answers for teacher perception using the Likert scale with the perception level was expressed in the form of the lowest score 1 (one) to the highest score of 4 (four) for positive statements and the opposite meaning is used for negative statements $[10,11]$. Data related to teacher's knowledge of ethnoscience, teacher experience in applying ethnoscience in chemical learning as well as difficulties faced by teachers in developing student worksheet with an ethnoscience approach were also studied in this study. The data is then descriptively analyzed to describe the teacher's perception of the worksheet with ethnoscience. The teacher's perception categorized according to the criteria in Table 1 [12].

TABLE I. TEACHER PERCEPTION CATEGORY

\begin{tabular}{|l|l|}
\hline \multicolumn{1}{|c|}{ Category } & \multicolumn{1}{c|}{ Score $(\mathbf{X})$} \\
\hline Very good & $\mathrm{X}>\mathrm{Mi}+1,5 \mathrm{SDi}$ \\
\hline Good & $\mathrm{Mi} \mathrm{s.d}(\mathrm{Mi}+1,5 \mathrm{SDi})$ \\
\hline Less good & $\mathrm{Mi}-1,5 \mathrm{Sdi} . \mathrm{d}<\mathrm{Mi}$ \\
\hline Not good & $\mathrm{X}<\mathrm{Mi}-1,5 \mathrm{Sdi}$ \\
\hline
\end{tabular}

\section{RESULTS AND DISCUSSION}

This section shows the teacher's perceptions data on students' worksheet containing ethnoscience for technical, content, and construct aspects (Table 2).

TABLE II. TEACHER's PERCEPTIONS ON THE TECHNICAL ASPECT OF STUDENT WORKSHEETT

\begin{tabular}{|l|l|l|l|}
\hline \multicolumn{1}{|c|}{ Interval } & \multicolumn{1}{|c|}{ F } & \multicolumn{1}{|c|}{ Fr $(\%)$} & \multicolumn{1}{c|}{ Category } \\
\hline$>19,5$ & 7 & 20,6 & Very good \\
\hline 15 s.d 19,5 & 27 & 79,2 & Good \\
\hline 10,5 s.d $<15$ & 0 & 0 & Less good \\
\hline$<10,5$ & 0 & 0 & Not good \\
\hline
\end{tabular}

$\mathrm{F}=$ frequency; $\mathrm{Fr}=$ Relative frequenc,

Teacher's perceptions on the technical aspects of the student worksheet are in the good category, especially in the attractive appearance, as well as the choice of fonts, and the combination of pictures and writing can clearly convey messages to users. The pictures contained in the student worksheet such as batik Sasambo and Jaje Timbung have been well known by students and teachers so that they can motivate to learn more meaningfully. Appearance is the main thing in student worksheet [13]. Student worksheet that is full of words will convey the impression of being bored and boring, but the use pictures also should not cause the message to not be conveyed properly.

Teachers' perceptions of the content aspects of the student worksheet with the ethnocentric approach are included in the very good category with an average score of 38.40 , and the frequency distribution is shown in Table 3.

TABLE III. TEACHER's PERCEPTION OF THE CONTENT ASPECTS OF STUDENT WORKSHEET

\begin{tabular}{|l|l|l|l|}
\hline \multicolumn{1}{|c|}{ Interval } & \multicolumn{1}{|c|}{ F } & \multicolumn{1}{|c|}{ Fr (\%) } & \multicolumn{1}{c|}{ Category } \\
\hline$>35,75$ & 20 & 58,8 & Very good \\
\hline 27,5 s.d 35,75 & 14 & 41,2 & Good \\
\hline 19,25 s.d $<27,5$ & 0 & 0 & Less good \\
\hline$<19,25$ & 0 & 0 & Not good \\
\hline
\end{tabular}

Most of the teachers were of the view that the content of the student worksheet that used the local culture, namely batik Sasambo and jaje timbung, was very relevant to the subject matter of electrolyte and non-electrolyte solutions, as well as colloids. The content of the student worksheet is also according to the competencies achieved. The relationship between the original scientific concepts that students have known with the chemical science they are studying makes learning more meaningful.

The teacher realizes that student worksheet with an ethnocentric approach is a very good medium for approaching chemical concepts with daily life around students and at the same time instilling the inner values of the nation's culture contained therein. The process of internalizing a culture into learning is one of the strategies for developing critical thinking skills of students with a contextual approach [14]. Thus, learning with the ethnocentric approach is an effective and contextual approach. This is in line with the results of research that student's ability to solve problems through contextual learning model is more effective than conventional learning [15].

The next teacher's perception of the student worksheet construct aspect with the ethnocentric approach, resulted in an average score of 30.2, including the good category (Table 4).

TABLE IV. TEACHER's PERCEPTION ON THE CONSTRUCTIVE ASPECTS OF STUDENT WORKSHEET

\begin{tabular}{|l|l|l|l|}
\hline \multicolumn{1}{|c|}{ Interval } & \multicolumn{1}{|c|}{ F } & \multicolumn{1}{|c|}{ Fr $(\%)$} & \multicolumn{1}{c|}{ Category } \\
\hline$>32,5$ & 12 & 35,3 & Very good \\
\hline 25 s.d 32,5 & 22 & 64,7 & good \\
\hline 17,5 s.d $<25$ & 0 & 0 & Less good \\
\hline$<17,5$ & 0 & 0 & Not good \\
\hline
\end{tabular}

Student worksheet contains ethnoscience according to teacher perceptions that have been arranged according to the level of development of students both from the aspect of language and the sequence of concepts so that it can represent messages or material that students must learn. In preparing teaching materials, it is best to avoid sentences that have 
multiple or ambiguous meanings so that there are no misconceptions [16].

The results of this study descriptively illustrate that teachers tend to have good perceptions about ethnoscience-based student worksheet. This could indicate the hope that student worksheet with an ethnocentric approach can be used in chemistry learning in the classroom. Despite the fact that there are still many obstacles faced by teachers if they have to compile their own student worksheet that integrates ethnocentric aspects.

Culture and learning are two things that cannot be separated because culture has a major contribution to the learning process and if chemistry learning in schools does not pay attention to the culture of students, the consequence is that students will reject or accept only some of the scientific concepts developed in learning.

\section{CONCLUSIONS}

The integration of the ethnoscience approach to learning resources may facilitate the development of human thought to see science not only as systematic knowledge, but also as a way of thinking. Based on the results of the research and analysis can be concluded that the chemistry teacher's perception of the student worksheets using the ethnoscience approach was valued significantly good for supplement the chemistry teaching process for students.

\section{REFERENCES}

[1] A.J. Pitoyo, Triwahyudi, and Hari, "Dynamic of Ethnic Development in Indonesia in the Context of National Unity, Population, Gajah Mada University, vol. 25 , no. $1,2017$.
[2] S. Okechukwu, Abonyi, A. Lawrence and Njoku, "Innovations in Science and Technology Education: A Case for Ethnoscience Based Science Classrooms," International Journal of Scientific and Engineering Research, Volume 5, Issue 1, 2014.

[3] O. Abonyi, "Effect of an Ethnoscience Based Instructional Package on Student Conception of Scientif Phenomena," accessed on January 2020. https://www.researchgate.net/, 2017.

[4] Sudarmin, Ethnoscience Based Science Learning Model to Instill Conservation Character Values and Scientific Literacy, Semarang: Semarang University, 2014.

[5] E. Tandililing, Pengembangan etnosain dalam pembelajaran pendidikan sain di sekolah. Diakses pada 1 September 2020. https://fkip.untan.ac.id

[6] G. Aikenhead and O.J. Jegede, "Cross-Cultural Science Education: A Cognitive Explanation of a Cultural Phenomenon," Joumal of Research in Science Teaching, vol 36, pp. 269-287, 1999.

[7] D. Baker and Taylor, "The effect of culture on the learning of science in non-western countries: the result of and integrated research review,' Intenational Journal of Science Education, no. 16, pp. 1- 16, 1995.

[8] A. Fibonacci and Sudarmin, "Development Fun-Chem Learning Materials Integrated SocioScience Issues to Increase Students Scientific Literacy. International Journal of Science and Research (IJSR),” vol. 3 Issue 11, November 2014, 2015.

[9] H.A. Alismail, "Multicultural Education: Teachers' Perceptions and Preparation", Journal of Education and Practice, vol. 7, no. 11, 2016.

[10] W. Nurkancana and P.P.N. Sunartana, Education Evaluation, Surabaya: National Business, 1986.

[11] F. Nussbeck, Scale Construction Methods. Statisticts and Models, http://www.affectivesciences.org/system/files/page2087/scale_constructions.pdf, 2009.

[12] S. Hadi, Statistics Volume 2, Yogyakarta: Andi Offset, 2004.

[13] M. Zahary, Development of LKPD Using a Multicultural Approach to Improve Students Ability to Understand Mathematical Concepts and Social Attitudes, Thesis, Lampung: Lampung University, 2017.

[14] A.W. Wisudawati dan E. Sulistyowati, Science Learning Methodology. Jakarta: Bumi Aksara, 2014.

[15] E. Nurvitasari, R.Z. Maarebia, and N.B. Sumanik, "The effectiveness of applying contextual approach based on environment toward chemistry learning achievement and scientific attitude", IOP Conf. Series: Earth and Environmental Science, 343- 012229, 2019.

[16] J.D. Parera, Basic of Syntactic Analysis. Jakarta: Erlangga, 2009 